\title{
Hypercalciuria Due to Combined Growth Hormone and Calcitriol Therapy in Uremia: Effects of Growth Hormone on Mineral Homeostasis in $75 \%$ Nephrectomized Weanling Rats
}

\author{
GAD KAINER,' MITSURO NAKANO, ${ }^{2}$ F. STANFORD MASSIE, JR., JOHN W. FOREMAN, AND \\ JAMES C. M. CHAN \\ Nephrologv Division, Children's Medical Center, and the Department of Pediatrics, Medical College of Virginia \\ Health Sciences Division of Virginia Commonwealth University, Richmond, Virginia 23298-0498
}

\begin{abstract}
The administration of growth hormone (GH) in conjunction with calcitriol in uremia may increase urinary calcium and decrease renal phosphate excretion, which could have an adverse effect on the kidney in chronic renal insufficiency. The effect of $40 \mathrm{~d}$ of ovine GH, calcitriol, and the combination of GH and calcitriol on mineral excretion was studied in rapidly growing uremic rats. Uremia was produced by $75 \%$ nephrectomy, and the animals were fed a diet containing $8 \%$ protein with equal quantities of calcium $(0.6 \%)$ and phosphate $(0.6 \%)$. The uremic rats treated with ovine $\mathrm{GH}$ were significantly longer and heavier than the uremic control rats and the uremic rats treated with calcitriol alone. However, the combination of calcitriol and GH abolished the beneficial effect of GH on growth and increased urinary calcium excretion 4-fold over uremic controls whether expressed as calcium excretion per $100 \mathrm{~g}$ body weight, urine calcium to creatinine ratio, or as fractional calcium excretion. Calcitriol therapy alone also significantly increased calcium excretion, but not to the extent that the combination therapy did. This increased urinary calcium excretion in the GH plus calcitriol group was not associated with an increase in calcium and sodium intake, plasma ionized calcium, or urinary sodium excretion. The calcium content of the femurs from all uremic rat groups was significantly lower than that of the sham control rats; however, there was also no further decrease in bone calcium content in the GH plus calcitriol group compared with uremic controls. This indicated that bone was not the source of this excess urinary calcium. Our data indicate that the combination of $\mathrm{GH}$ and calcitriol significantly increases urinary calcium excretion in growing uremic rats. These results suggest the need to monitor such untoward side effects in children with chronic renal failure who receive this combination of therapies. (Pediatr Res 30: 528-533, 1991)
\end{abstract}

\section{Abbreviations}

$\mathrm{SC}$, sham control

UC, uremic control

Received October 9, 1990; accepted July 18, 1991.

Correspondence and reprint requests: J. C. M. Chan, Box 498, MCV Station, Richmond, VA 23298-0498.

Supported by Grants R01 DK31370 and R01 DK39336 from the National Institutes of Health.

'Present address: Prince of Wales Children's Hospital, Randwick, NSW 2031, Australia.

2 Present address: Department of Pediatrics and Child Health, Kurume University School of Medicine, 67 Asahi-machi, Kurume City, Japan 830.
UGH, uremic rat treated with growth hormone

$\mathrm{UD}$, uremic rat treated with 1,25-dihydroxyvitamin $\mathrm{D}_{3}$ (calcitriol)

UDGH, uremic rat treated with growth hormone and 1,25dihydroxyvitamin $\mathrm{D}_{3}$

GH, growth hormone

oGH, ovine growth hormone

$F_{P}$, fractional excretion of phosphate

Children with chronic renal insufficiency continue to be growth retarded $(1-4)$ despite improved understanding of vitamin $\mathrm{D}$ and mineral requirements $(5-11)$, correction of acidosis and electrolyte disorders, enhanced calorie and nutritional management $(12,13)$, and adequate dialysis.

Although the mechanisms underlying the inhibitory effects of uremia on growth remain unclear, administration of supraphysiological doses of GH to uremic animals (14-16) and to a small number of uremic children (17), over relatively short intervals, has been shown to improve growth. Whether this will significantly improve the final adult stature remains to be determined.

Treatment of chronic renal failure in children usually includes one of the polar vitamin $\mathrm{D}$ metabolites. The effects of $\mathrm{GH}$ alone or in combination with calcitriol administration on renal electrolyte handling and mineral balance in uremia are largely unknown. However, this information is vitally important. Increased serum concentrations of calcium and phosphate are associated with a number of problems in renal failure including calciphylaxis, pruritis, aggravation of secondary hyperparathyroidism, and possibly progression of renal failure (18). However, several lines of evidence have been recently presented that suggested that calcium and phosphate disorders play a secondary and minor role in the progression of renal failure.

If hypercalciuria is significantly aggravated by vitamin D combined with GH therapy, it may lead to urolithiasis, which would be an important complication to be further defined in humans. Therefore, we investigated the effects of supraphysiologic doses of $\mathrm{GH}$ alone and in combination with calcitriol on sodium, calcium, magnesium, and phosphate homeostasis using a $75 \%$ nephrectomy uremic, weanling rat model.

\section{MATERIALS AND METHODS}

The GH used in this study was oGH, supplied by the National Institute of Diabetes and Digestive and Kidney Diseases, Be- 
thesda, MD (ovine oGH-15 AFP-7649C). The oGH was prepared daily in $0.15 \mathrm{M} \mathrm{NaCl}$ with $0.05 \mathrm{M}$ sodium bicarbonate adjusted with $0.1 \mathrm{~N} \mathrm{NaOH}$ to a $\mathrm{pH}$ of 9.2. Calcitriol was prepared in safflower oil weekly and kept refrigerated in a foil-wrapped brown glass bottle until use. The low protein $(8 \%)$ rat food, containing $0.6 \%$ calcium and $0.6 \%$ phosphorus (Table 1 ), was purchased from United States Biochemical Corporation, Cleveland, $\mathrm{OH}$. The diet was sufficient in protein, minerals, and vitamins. The low $8 \%$ protein diet was chosen to protect the compromised kidney from the effects of a high-protein intake. Twenty-threed-old, weanling, male, Sprague-Dawley rats were purchased from Charles River Laboratories, Inc., Raleigh, NC.

Experimental protocol. The experimental protocol was ap-

Table 1. Low-protein diet

\begin{tabular}{lc}
\hline Protein content (casein) & $8.0 \%$ \\
Corn starch & $28.0 \%$ \\
Sucrose & $50.0 \%$ \\
Cottonseed oil & $10.0 \%$ \\
Calcium & $0.6 \%$ \\
Phosphorus & $0.6 \%$ \\
Sodium & $0.2 \%$ \\
Vitamin $\mathrm{D}_{2}$ & 1000 units/pound \\
\hline
\end{tabular}

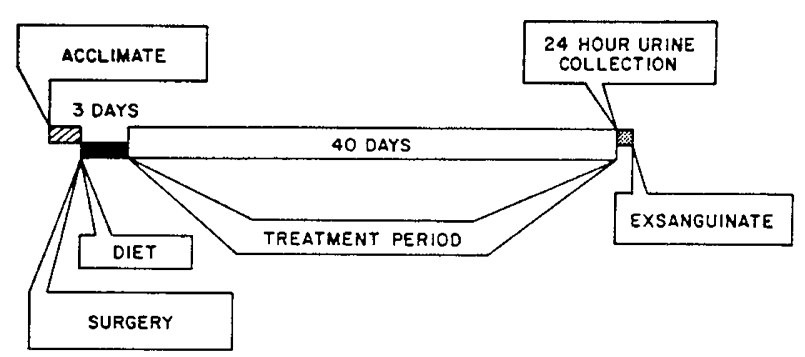

Fig. 1. Experimental protocol: 129 weanling rats, aged $23 \mathrm{~d}$, fed a diet consisting of $8 \%$ protein, $0.6 \%$ calcium, and $0.6 \%$ phosphorus. Surgery consisted of one-stage right nephrectomy and left heminephrectomy to create $75 \%$ nephrectomy. Sham-operated rats underwent identical operative procedures up to and including decapsulation of the kidneys. Treatment consisted of daily injections of $0.5 \mathrm{mg}$ of oGH, 20 $\mathrm{ng} / \mathrm{kg}$ of oral calcitriol, or both. Sham-operated and uremic animals not receiving medications were given vehicles only.

Table 2. Experimental groups

\begin{tabular}{ccl}
$\begin{array}{c}\text { Experimental } \\
\text { group }\end{array}$ & $\begin{array}{c}\text { No. of } \\
\text { animals }\end{array}$ & \multicolumn{1}{c}{ Treatment } \\
\hline SC & 10 & Vehicles only \\
UC & 30 & Vehicles only \\
UD & 30 & $20 \mathrm{ng} / \mathrm{kg}$ calcitriol \\
UG & 29 & $0.5 \mathrm{mg} / \mathrm{d} \mathrm{GH}$ \\
UDGH & 30 & Both calcitriol and GH \\
\hline
\end{tabular}

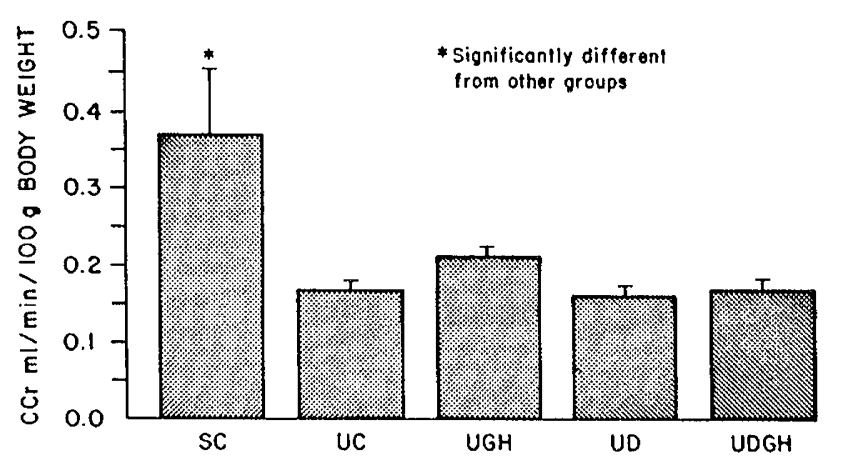

Fig. 2. Creatinine clearances $(\mathrm{CCr})$ in $\mathrm{mL} / \mathrm{min} / 100 \mathrm{~g}$ body wt in $\mathrm{SC}$, UC, UGH, UD, and UDGH groups. The creatinine clearance of the SC group was significantly higher than all other groups.

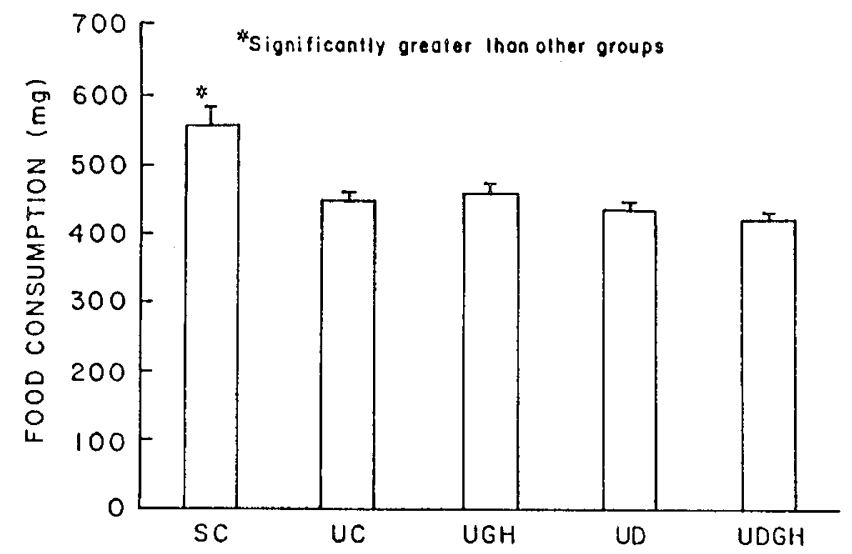

Fig. 3. Total food consumption over the treatment period by $\mathrm{SC}$, UC, UGH, UD, and UDGH groups. *, Significantly increased food consumption over all other groups.

Table 3. Food and mineral intake*

\begin{tabular}{lccc}
\hline Group & $\begin{array}{c}\text { Total } \\
\text { food intake } \\
(\mathrm{g})\end{array}$ & $\begin{array}{c}\text { Calcium intake } \\
(\mathrm{mg})\end{array}$ & $\begin{array}{c}\text { Average daily } \\
\text { food intake } \\
(\mathrm{g} / 100 \mathrm{~g} \text { body } \mathrm{wt})\end{array}$ \\
\hline SC & $559 \pm 24 \dagger$ & $3.4 \pm 0.1 \dagger$ & $10.4 \pm 0.2$ \\
UC & $449 \pm 10$ & $2.7 \pm 0.1$ & $10.3 \pm 1.0$ \\
UGH & $460 \pm 14$ & $2.8 \pm 0.1$ & $10.1 \pm 0.2$ \\
UD & $436 \pm 10$ & $2.6 \pm 0.1$ & $10.1 \pm 0.1$ \\
UDGH & $421 \pm 10$ & $2.5 \pm 0.1$ & $9.7 \pm 0.1$ \\
\hline
\end{tabular}

* All data are expressed as the mean \pm SEM.

$\uparrow$ Significantly greater than the other groups $(p<0.002)$.

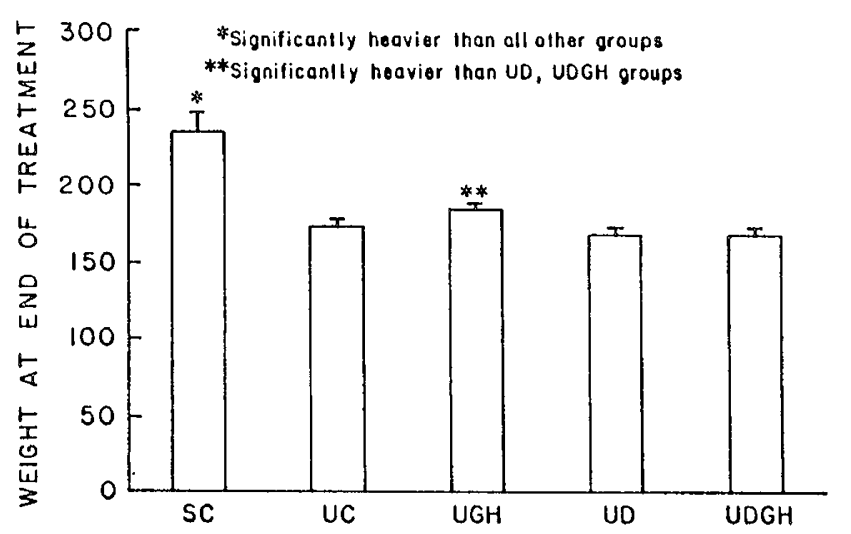

Fig. 4. Weight at the end of the treatment period in $\mathrm{g}$ of $\mathrm{SC}, \mathrm{UC}$, $\mathrm{UGH}, \mathrm{UD}$, and UDGH groups.

proved by Virginia Commonwealth University's Institutional Animal Care and Use Committee. The rats were received at 23 $\mathrm{d}$ of age, acclimated for 2-3 d (Fig. 1), and at $26 \mathrm{~d}$ of age they underwent a one-stage right nephrectomy and left heminephrectomy under anesthesia with $50 \mathrm{mg} / \mathrm{kg}$ of pentobarbital. Shamoperated rats underwent identical operative procedures up to and including decapsulation of the kidneys. During the 3-d postoperative recovery period and throughout the experimental period, the rats were housed in individual wire cages at $22^{\circ} \mathrm{C}$ in a light/dark cycle of $12 \mathrm{~h}$ and given ad libitum access to the experimental diet and deionized water.

At age $29 \mathrm{~d}$, the uremic rats were assigned to one of four groups as shown in Table 2 . The daily dose of $0.5 \mathrm{mg}$ oGH was injected s.c. at $0900 \mathrm{~h}$. Calcitriol in oil $(20 \mathrm{ng} / \mathrm{kg})$ was gavaged daily, and the dose was adjusted every other day after weighing the rat to maintain the dose at $20 \mathrm{ng} / \mathrm{kg}$. Sham-operated and uremic animals not receiving medications were injected or gavaged with vehicles only. Food intake was measured every other day. The average food intake per $100 \mathrm{~g}$ body weight for each rat 
Table 4. Growth parameters

\begin{tabular}{|c|c|c|c|c|}
\hline Group & $\begin{array}{c}\text { Initial wt } \\
(\mathrm{g})\end{array}$ & $\begin{array}{c}\text { Final wt } \\
(\mathrm{g})\end{array}$ & $\begin{array}{l}\text { Initial length } \\
(\mathrm{cm})\end{array}$ & $\begin{array}{l}\text { Final length } \\
(\mathrm{cm})\end{array}$ \\
\hline $\mathrm{SC}$ & $75.94 \pm 2.65$ & $234.84 \pm 12.82^{*}$ & $26.82 \pm 0.55$ & $40.90 \pm 0.86^{*}$ \\
\hline UC & $74.71 \pm 0.93$ & $173.68 \pm 4.05$ & $27.19 \pm 0.18$ & $38.55 \pm 0.28$ \\
\hline UGH & $74.60 \pm 0.96$ & $183.12 \pm 4.24 \dagger$ & $27.14 \pm 0.20$ & $39.60 \pm 0.29 \dagger$ \\
\hline UD & $74.42 \pm 0.88$ & $166.94 \pm 4.31$ & $27.12 \pm 0.14$ & $38.08 \pm 0.30$ \\
\hline UDGH & $73.70 \pm 0.81$ & $167.41 \pm 3.64$ & $26.89 \pm 0.16$ & $38.29 \pm 0.30$ \\
\hline
\end{tabular}

* Significantly larger than all other groups.

† Significantly larger than the UD and UDGH groups.

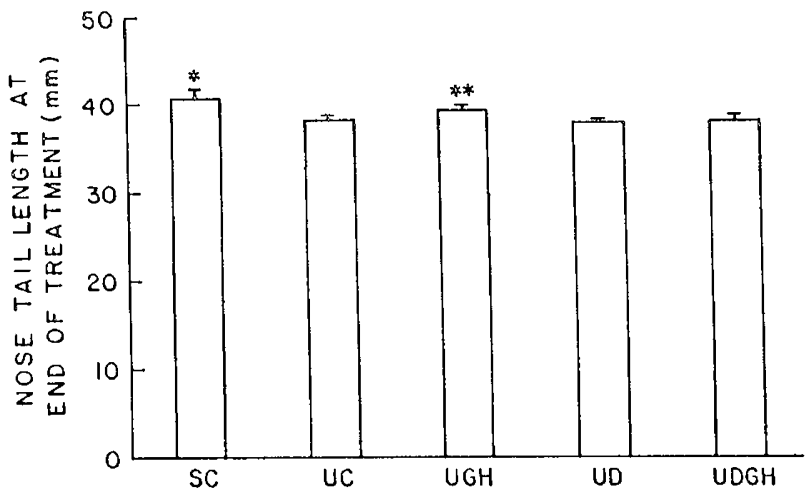

Fig. 5. Nose-to-tail length at the end of the treatment period. *, Significantly longer than UC, UD, and UDGH groups. **, Significantly longer than UC, UD, and UDGH groups.

was obtained by calculating the average daily food consumption and dividing this by the average weight for the rat over the time of the experiment.

At completion of the 40-d experimental period, the rats were placed in individual Nalgene metabolic cages (Sybron Corp., Rochester, NY), and fasting (water ad libitum) 24-h urine collections were taken. After the urine collections, the rats were anesthetized and exsanguinated by cardiac puncture.

Plasma ionized and total calcium concentration was measured immediately after separation from the cells using a Nova 7 Electrolyte Analyzer (Nova Biomedical, Waltham, MA). Serum and urine collected for electrolyte analysis were stored at $-20^{\circ} \mathrm{C}$. Urinary sodium was measured using a Beckman E4A analyzer (Beckman Instruments, Inc., Brea, CA). Serum and urine inorganic phosphorus were measured using the method of Baginski et al. (19). Serum and urine magnesium and calcium were measured using a Perkin-Elmer model 5000 atomic absorption spectrophotometer (Perkin-Elmer Corp., Norwalk, CT) (20). Creatinine was measured using a Beckman Creatinine Analyzer II. Creatinine clearance was calculated using the standard formula. The percent of fractional excretion (\%FE) of an electrolyte was calculated from the following equation: $\% \mathrm{FE}_{\mathrm{x}}=\left[\left(\mathrm{U}_{\mathrm{x}}\right.\right.$ times $\left.\mathrm{P}_{\mathrm{Cr}}\right)$ divided by $\left(\mathrm{P}_{\mathrm{x}}\right.$ times $\left.\left.\mathrm{U}_{\mathrm{Cr}}\right)\right] \times 100$, where $\mathrm{x}$ is the electrolyte, $\mathrm{Cr}$ is creatinine, $U$ is urine, and $P$ is plasma. The fractional excretion of calcium was calculated using the plasma ionized calcium value.

The left femur was removed after the rats were killed and was cleaned of all soft tissue and desiccated at $130^{\circ} \mathrm{C}$ for $24 \mathrm{~h}$. Total bone mineral content was measured by atomic absorption spectrophotometry $(21,22)$ after dry ashing at $580^{\circ} \mathrm{C}$ in borosilicate test tubes using a Temp-Master muffle furnace (Jelrus Dental Products Corp., New Hyde Park, NY).

Statistics. All data were expressed as mean \pm SEM. Analysis of variance was done by Tukey's studentized range, honestly significant difference test for multiple group comparisons with level of significance set at $\alpha=0.05$ (95\% confidence limits) using the Statistical Analysis System (SAS User's Guide: Basic, Version 5 Edition, 1985, SAS Institute, Inc., Cary, NC).

\section{RESULTS}

The mean creatinine clearance in each uremic group was significantly reduced when compared with the sham-operated control group. There were no significant differences between the mean creatinine clearances of the uremic groups (Fig. 2). The sham-operated control animals ate significantly more food over the course of the experiment than the uremic animals (Fig. 3) and, therefore, took in more minerals than the uremic animals (Table 3). There was no difference in the total food intake between the various uremic groups. The average daily food intake per $100 \mathrm{~g}$ body weight was not different between the groups.

Uremic rats treated for $40 \mathrm{~d}$ with ovine $\mathrm{GH}$ therapy were heavier (Fig. 4 and Table 4) and longer (Fig. 5, Table 4) when compared with uremic control rats, an effect that has been shown previously for both rat and human GH. Calcitriol alone had no effect on growth in uremic rats and abolished the beneficial growth effect of $\mathrm{GH}$.

The serum concentrations of total calcium, ionized calcium, magnesium, and phosphate are shown in Table 5. There was no statistically significant difference between the serum concentrations of these ions among the uremic groups. The mean serum total calcium in the UD group was significantly higher than the mean of the SC group. The mean serum phosphate concentration of the UDGH group was significantly greater than that of the SC

Table 5. Serum divalent ions*

\begin{tabular}{|c|c|c|c|c|}
\hline Group & Calcium & $\begin{array}{l}\text { Ionized } \\
\text { calcium }\end{array}$ & Magnesium & Phosphate \\
\hline $\mathrm{SC}$ & $\begin{array}{c}2.65 \pm 0.03 \\
(10.61 \pm 0.12)\end{array}$ & $\begin{array}{c}1.51 \pm 0.03 \\
(6.00 \pm 0.12)\end{array}$ & $\begin{array}{c}0.82 \pm 0.02 \\
(2.00 \pm 0.06)\end{array}$ & $\begin{array}{c}2.72 \pm 0.09 \\
(8.42 \pm 0.28)\end{array}$ \\
\hline $\mathrm{UC}$ & $\begin{aligned} 2.71 & \pm 0.02 \\
(10.85 & \pm 0.09)\end{aligned}$ & $\begin{array}{c}1.52 \pm 0.01 \\
(6.04 \pm 0.04)\end{array}$ & $\begin{array}{c}1.00 \pm 0.02 \\
(2.42 \pm 0.05) \dagger\end{array}$ & $\begin{array}{c}3.15 \pm 0.07 \\
(9.75 \pm 0.23)\end{array}$ \\
\hline UGH & $\begin{array}{c}2.72 \pm 0.02 \\
(10.90 \pm 0.08)\end{array}$ & $\begin{array}{c}1.52 \pm 0.02 \\
(6.04 \pm 0.08)\end{array}$ & $\begin{array}{c}0.96 \pm 0.02 \\
(2.34 \pm 0.06)\end{array}$ & $\begin{array}{c}3.06 \pm 0.09 \\
(9.49 \pm 0.28)\end{array}$ \\
\hline UD & $\begin{array}{c}2.77 \pm 0.01 \\
(11.11 \pm 0.05) \dagger\end{array}$ & $\begin{array}{c}1.52 \pm 0.01 \\
(6.04 \pm 0.04)\end{array}$ & $\begin{array}{c}1.00 \pm 0.03 \dagger \\
(2.43 \pm 0.07) \dagger\end{array}$ & $\begin{array}{c}3.22 \pm 0.12 \\
(9.98 \pm 0.37)\end{array}$ \\
\hline UDGH & $\begin{array}{c}2.76 \pm 0.02 \\
(11.08 \pm 0.10)\end{array}$ & $\begin{array}{c}1.52 \pm 0.02 \\
(6.04 \pm 0.08)\end{array}$ & $\begin{aligned} 1.04 & \pm 0.03 \dagger \\
(2.52 & \pm 0.08) \dagger\end{aligned}$ & $\begin{aligned} & 3.39 \pm 0.16 \dagger \\
&(10.50 \pm 0.51) \dagger\end{aligned}$ \\
\hline
\end{tabular}

* All data are expressed as mean \pm SEM. Values on top are expressed as mmol/L; values in parentheses are expressed as $\mathrm{mg} / \mathrm{dL}$

$\uparrow$ Significantly greater than the SC group only. 
Table 6. Urinary electrolyte excretion*

\begin{tabular}{|c|c|c|c|c|c|}
\hline Group & Calcium $\dagger$ & $\mathrm{Ca} / \mathrm{Cr}$ & $\mathrm{Mg} / \mathrm{Cr}$ & $\mathrm{Na} \S$ & $\mathrm{Na} / \mathrm{Cr} \|$ \\
\hline SC & $\begin{array}{c}0.0025 \pm 0.0002 \\
(0.10 \pm 0.01)\end{array}$ & $\begin{array}{c}0.04 \pm 0.01 \\
(0.04 \pm 0.01)\end{array}$ & $\begin{array}{c}0.29 \pm 0.03 \\
(0.29 \pm 0.03)\end{array}$ & $0.27 \pm 0.03$ & $\begin{array}{c}0.0118 \pm 0.0000 \\
(0.10 \pm 0.00)\end{array}$ \\
\hline UC & $\begin{array}{c}0.0047 \pm 0.0005 \\
(0.19 \pm 0.02)\end{array}$ & $\begin{array}{c}0.08 \pm 0.01 \\
(0.08 \pm 0.01)\end{array}$ & $\begin{array}{c}0.40 \pm 0.039 \\
(0.40 \pm 0.03) \uparrow\end{array}$ & $0.26 \pm 0.07$ & $\begin{aligned} 0.0123 & \pm 0.0010 \\
(0.12 & \pm 0.01)\end{aligned}$ \\
\hline $\mathrm{UGH}$ & $\begin{array}{c}0.0087 \pm 0.0015 \\
(0.35 \pm 0.06)\end{array}$ & $\begin{array}{c}0.16 \pm 0.03 \\
(0.16 \pm 0.03)\end{array}$ & $\begin{array}{c}0.43 \pm 0.03 \pi \\
(0.43 \pm 0.03) \pi\end{array}$ & $0.32 \pm 0.07$ & $\begin{array}{c}0.0149 \pm 0.0010 \\
(0.14 \pm 0.01)\end{array}$ \\
\hline UD & $\begin{array}{c}0.0122 \pm 0.0022^{* *} \\
(0.49 \pm 0.09)^{* *}\end{array}$ & $\begin{array}{c}0.19 \pm 0.02^{* *} \\
(0.19 \pm 0.02)^{* *}\end{array}$ & $\begin{array}{c}0.42 \pm 0.02 \pi \\
(0.42 \pm 0.02) \uparrow\end{array}$ & $0.30 \pm 0.11$ & $\begin{array}{c}0.0139 \pm 0.0010 \\
(0.12 \pm 0.01)\end{array}$ \\
\hline UDGH & $\begin{array}{c}0.0192 \pm 0.0025 \dagger \dagger \\
(0.77 \pm 0.10) \dagger \dagger\end{array}$ & $\begin{array}{r}0.33 \pm 0.04 \dagger \dagger \\
(0.33 \pm 0.04) \dagger \dagger\end{array}$ & $\begin{array}{c}0.44 \pm 0.02 \pi \\
(0.44 \pm 0.02)\end{array}$ & $0.34 \pm 0.24$ & $\begin{aligned} 0.0160 & \pm 0.0010 \\
(0.14 & \pm 0.01)\end{aligned}$ \\
\hline
\end{tabular}

* All data are expressed as mean $\pm \mathrm{SEM}$; $\mathrm{Cr}$, creatinine.

† For each group, values on top are in mmol/100 $\mathrm{g}$ body wt/d and values in parentheses are in $\mathrm{mg} / 100 \mathrm{~g}$ body wt/24 $\mathrm{h}$.

¥Values on top are in $\mathrm{mmol} / \mathrm{mmol}$; values in parentheses are in $\mathrm{mg} / \mathrm{mg}$.

$\S$ Values are in $\mathrm{mmol} / 100 \mathrm{~g}$ body $\mathrm{wt} / 24 \mathrm{~h}$.

$\|$ Values on top are in $\mathrm{mmol} / \mu \mathrm{mol}$; values in parentheses are in $\mathrm{mmol} / \mathrm{mg}$.

I Significantly greater than SC only.

** Significantly greater than UC and SC.

$\dagger+$ Significantly greater than all other groups.

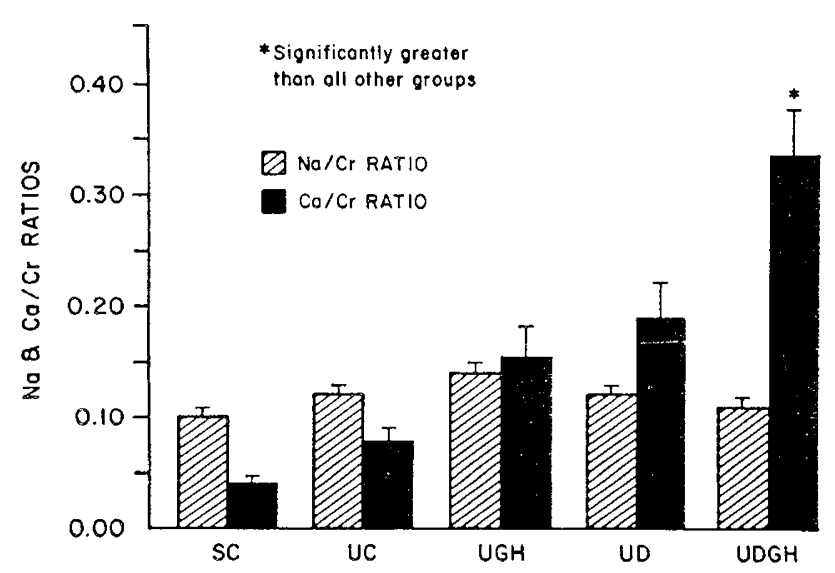

Fig. 6. Urinary sodium and calcium to creatinine ratios. Sodium to creatinine ratio $(\mathrm{Na} / \mathrm{Cr})$ in $\mathrm{mmol} / \mathrm{mg}$. Calcium to creatinine ratio $(\mathrm{Ca} /$ $(r)$ in $\mathrm{mg} / \mathrm{mg}$.

Table 7. Fractional excretion of divalent ions*

\begin{tabular}{lccl}
\hline Group & $\mathrm{FE}_{\mathrm{Ca}}(\%)$ & $\mathrm{FE}_{\mathrm{Mg}}(\%)$ & \multicolumn{1}{c}{$\mathrm{FE}_{\mathrm{P}}(\%)$} \\
\hline $\mathrm{SC}$ & $0.37 \pm 0.05$ & $9.09 \pm 1.69$ & $23.11 \pm 3.79$ \\
$\mathrm{UC}$ & $1.42 \pm 0.15$ & $17.81 \pm 1.80 \dagger$ & $43.52 \pm 4.40 \dagger$ \\
$\mathrm{UGH}$ & $2.33 \pm 0.46$ & $16.23 \pm 1.55$ & $36.78 \pm 2.95$ \\
$\mathrm{UD}$ & $3.52 \pm 0.34$ & $20.90 \pm 1.42 \dagger$ & $46.98 \pm 2.41 \dagger$ \\
$\mathrm{UDGH}$ & $6.40 \pm 1.20 \ddagger$ & $17.94 \pm 1.10 \dagger$ & $42.60 \pm 2.91 \dagger$ \\
\hline
\end{tabular}

${ }^{*} \mathrm{FE}_{\mathrm{x}}(\%)$ is fractional excretion of ion expressed as a percentage. All data are expressed as mean $\pm \mathrm{SEM}$.

$\uparrow$ Significantly larger than SC group only.

¥ Significantly larger than all other groups.

group. The mean serum magnesium concentrations of the UC, UD, and UDGH groups were higher than that of the SC group.

The 24-h urinary excretion of calcium per $100 \mathrm{~g}$ body wt is shown in Table 6 . The UDGH group excreted a significantly greater amount of calcium per day than all other groups. The 24-h mean urinary calcium excretion of the UD group was significantly greater than that of the UC and SC groups. Factoring the 24-h urinary calcium by the urinary creatinine (Fig. 6) revealed a similar pattern of significantly increased calcium excretion in the UDGH group compared with all the other groups and also an increased calcium excretion in the UD group compared with the UC and SC groups. The sodium/creatinine ratio and the sodium excretion per d per $100 \mathrm{~g}$ body wt in the UD and UDGH groups were not different from those of the other groups, indicating that the greater calcium excretion in the UD

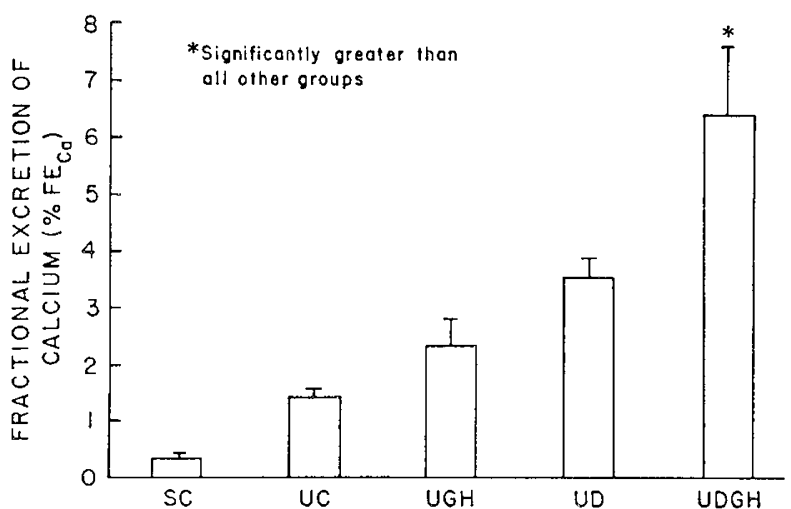

Fig. 7. Fractional excretion of calcium $\left(\% F E_{(u)}\right)$. Serum ionized calcium was used in the calculation.

and UDGH groups was not secondary to increased sodium excretion. The fractional excretion of calcium (Table 7, Fig. 7) was significantly higher in the UDGH rats when compared with all other groups.

$\mathrm{FE}_{\mathrm{P}}$ was significantly elevated in the UC, UD, and UDGH groups compared with that of the SC group. There was no statistical difference in the $\mathrm{FE}_{\mathrm{p}}$ between the uremic groups (Table 7). The $F_{P}$ in the UGH group was the lowest among the uremic groups and was not statistically greater than that of the sham controls. This suggests that GH can increase phosphate reabsorption in uremia, which could be an undesirable side effect of $\mathrm{GH}$ therapy in chronic renal failure.

The fractional excretion of magnesium was elevated in each of the uremic groups compared with that of the SC group; however, the difference between the means reached significance only for the UC, UD, and UDGH groups. There was no significant difference in fractional excretion of magnesium between the uremic groups (Table 7).

Bone mineral analysis. Bone weight and mineral content were normalized to $100 \mathrm{~g}$ body weight, and the results are presented in Table 8. The mean desiccated femur weights of the UGH, UD, and UDGH groups were significantly heavier than that of the SC group. Furthermore, the mean desiccated femur weight of the UDGH group was significantly greater than that of the UC group. However, the mean calcium content of the desiccated bones was significantly greater in the SC group compared with the means of the UC and UGH groups. The mean calcium content of dry bone in the UD group was significantly greater than that of the UGH group. There was no difference in the mean dry bone calcium content of the UDGH group and those 
Table 8. Bone mineral analysis*

\begin{tabular}{|c|c|c|c|c|}
\hline \multirow[b]{2}{*}{ Group } & \multirow{2}{*}{$\begin{array}{l}\text { Dry bone wt/ } \\
100 \text { g body wt }\end{array}$} & \multirow{2}{*}{$\begin{array}{l}\text { Bone ash wt/ } \\
100 \mathrm{~g} \text { body wt }\end{array}$} & \multicolumn{2}{|c|}{ Mineral wt $\dagger$} \\
\hline & & & Calcium & Magnesium \\
\hline $\mathrm{SC}$ & $0.184 \pm 0.003$ & $0.101 \pm 0.001$ & $\begin{array}{c}49.88 \pm 4.24 \ddagger \\
(199.9 \pm 1.7) \ddagger\end{array}$ & $\begin{array}{c}0.95 \pm 0.04 \\
(2.3 \pm 0.1)\end{array}$ \\
\hline UC & $0.198 \pm 0.002$ & $0.104 \pm 0.001$ & $\begin{array}{r}47.03 \pm 0.32 \\
(188.5 \pm 1.3)\end{array}$ & $\begin{array}{l}1.19 \pm 0.04 \\
(2.9 \pm 0.1)\end{array}$ \\
\hline $\mathrm{UGH}$ & $0.207 \pm 0.005 \S$ & $0.109 \pm 0.004$ & $\begin{array}{r}45.78 \pm 0.70 \\
(183.5 \pm 2.8)\end{array}$ & $\begin{array}{l}1.19 \pm 0.04 \\
(2.9 \pm 0.1)\end{array}$ \\
\hline UD & $0.208 \pm 0.003 \S$ & $0.111 \pm 0.001 \|$ & $\begin{array}{r}48.00 \pm 0.37 \pi \\
(192.4 \pm 1.5) \uparrow\end{array}$ & $\begin{array}{c}1.28 \pm 0.04 \\
(3.1 \pm 0.1)\end{array}$ \\
\hline UDGH & $0.214 \pm 0.003^{* *}$ & $0.112 \pm 0.001 \|$ & $\begin{array}{c}47.23 \pm 0.40 \\
(189.3 \pm 1.6)\end{array}$ & $\begin{array}{l}1.28 \pm 0.04 \S \\
(3.1 \pm 0.1) \S\end{array}$ \\
\hline
\end{tabular}

* All data are expressed as mean $\pm \mathrm{SEM}$.

$\dagger$ Values on top are expressed as $\mathrm{mmol} / \mathrm{g}$ dry bone $\mathrm{wt}$; values in parentheses are expressed as $\mathrm{mg} / \mathrm{g}$ dry bone wt.

$\$$ Significantly greater than UC and UGH.

$\$$ Significantly larger than SC only.

II Significantly greater than SC, UC, and UGH.

II Significantly greater than UGH only.

** Significantly larger than both SC and UC.

of the other groups. Each of the uremic groups had a mean femur magnesium content that was greater than that of the SC group, but this was statistically significant only for the UDGH group. There was no difference in femur magnesium content between the uremic groups.

\section{DISCUSSION}

The one-stage, $75 \%$ nephrectomized, chronic renal insufficiency weanling rat model allows experimental observation during the prepubertal period and through the pubertal rapid growth phase. Thus, the model simulates the pediatric patient with chronic renal insufficiency. To improve survival in our rats and to reduce the potential deleterious effects of a high protein diet and excessive phosphorus intake on the remnant kidney, all rats in our study were fed a diet containing $8 \%$ protein with equal quantities of calcium and phosphorus (14). Diets containing a relatively high protein content (over $20 \%$ protein) have been shown consistently to hasten the progression of remnant kidney sclerosis in uremic rats $(22,23)$. Diets containing less than $6 \%$ protein are deficient, but an $8 \%$ protein diet provides an adequate amount of protein to allow moderate weight gain (24). For maximal weight gain, a higher protein intake is necessary in uremic rats. It has been suggested that a high phosphate intake is associated with accelerated deterioration of renal function in uremic rats (25). However, protein intake appears to be much more important than any other nutrient in accelerating renal damage (24).

This study showed, as have others (14-16), that the administration of $\mathrm{GH}$ to uremic, weanling rats can improve their growth, an effect also noted in children with chronic renal failure (17). Calcitriol administration did not improve growth in these uremic rats, although it has been shown to improve growth in children with chronic renal failure (5). It is unclear why calcitriol did not improve growth, but it may be related to the low phosphorus content of the diet, which prevented a fall in calcitriol production, as has been shown in children with renal failure on restricted phosphorus diets (26). Thus, by restricting dietary phosphorus, these animals may not have needed supplemental calcitriol. Surprisingly, the growth-enhancing effect of GH therapy was lost when calcitriol was added to the regimen. The mechanism for this lack of effect is unclear.

The combination of calcitriol and GH led to marked hypercalciuria, whether expressed as calcium excretion per $100 \mathrm{~g}$ body $\mathrm{wt}$, as the ratio of calcium to creatinine, or as the fractional excretion of calcium. Calcitriol has clearly been associated with hypercalciuria in renal failure (11), and this was observed in the uremic rats given calcitriol alone. $\mathrm{GH}$ has also been shown to increase urinary calcium excretion both in humans (27) and in animals (28). This may be due, in part, to an increase in renal 1$\alpha$-hydroxylase activity with increased production of calcitriol and adsorption of dietary calcium $(29,30)$. GH administration alone increased urinary calcium excretion compared with the UC and the SC animals, but this did not reach statistical significance.

Increased urinary calcium excretion can result from increased serum ionized calcium concentrations, resulting in an increased filtered load. However, there was no difference in the mean serum ionized calcium concentrations between any of the groups. Another cause of increased urinary calcium excretion is increased dietary calcium and/or sodium intake (31). However, in our study, this was not the case because there was no difference in dietary intakes between uremic animal groups. In fact, the SC animals ingested more calcium and sodium than any of the uremic groups, yet this group had the lowest urinary calcium excretion. Therefore, increased urinary sodium excretion was not the cause of the hypercalciuria.

The source of the increased urinary calcium is next examined. The bone did not appear to be the source because the calcitriol (UD) group had the highest and the calcitriol plus GH (UDGH) group had the next highest bone calcium content of the uremic animals. Still, even these two groups had significantly less calcium compared with the SC group, underscoring the deleterious effect of uremia on bone calcification. On the other hand, bone magnesium content was increased in the uremic groups compared with the SC group, an effect previously noted (32). Further studies are necessary to elucidate whether the hypercalciuria is secondary to increased intestinal absorption, renal "leak," or both.

Another effect of $\mathrm{GH}$ on the kidney that could be deleterious in renal failure is the enhancement of phosphate reabsorption $(27,28)$. $\mathrm{FE}_{\mathrm{P}}$ was increased in all of the uremic rats. GH administration appeared to blunt this increased phosphate excretion in uremia because this group (UGH) had the smallest increase in $\mathrm{FE}_{\mathrm{p}}$ and the phosphate excretion of the UGH group was not statistically different from that of the SC group. The addition of calcitriol to $\mathrm{GH}$ abolished this antiphosphaturic effect of $\mathrm{GH}$. However, this group (UDGH) had the highest serum phosphate concentration. This elevated phosphate concentration was probably due to increased intestinal absorption under the influence of calcitriol and $\mathrm{GH}$ because the renal excretion was as great as in the UC group.

In conclusion, our studies indicate that marked hypercalciuria occurs in response to combined $\mathrm{GH}$ and calcitriol treatment in uremic rats. This complication, together with the potential risk 
of increased renal plasma flow and glomerular filtration rates from $\mathrm{GH}$ therapy $(33,34)$, raises concerns regarding the longterm safety of combined $\mathrm{GH}$ and calcitriol therapy in uremic children (35), despite the exciting promise of the beneficial effects of GH therapy in both children (36-38), and the elderly (39). However, the doses of $\mathrm{GH}$ given to the uremic rats in our study were greater than the doses currently used to treat nonuremic children with growth deficiency or adult elderly patients. Obviously, it is difficult and risky to extrapolate the results of this study in uremic rats to children with growth failure and chronic renal failure, but it does underscore the need to evaluate new therapies carefully for potential side effects.

Acknowledgments. The authors thank Daijin Ko, Ph.D., for statistical assistance, Martha D. Wellons and Faith S. Boyle, B.S., for technical assistance, Martha D. Massie, R.D., and Amy Perkins, B.S., for editorial assistance, and Marilyn Reilly and Betty Timozek for secretarial assistance. The ovine growth hormone was a gift of Dr. S. Raiti of the National Institute of Diabetes and Digestive and Kidney Diseases.

\section{REFERENCES}

1. Henning P. Tomlinson L. Rigden SPA, Haycock GB, Chantler C 1988 Longterm outcome of treatment of end-stage renal failure. Arch Dis Child 63:3540

2. Foreman JW. Chan JCM 1988 Chronic renal failure in infants and children. J Pediatr 1 13:793-800

3. Chesney RW 1987 Growth retardation in childhood renal disease: a hormonal or nutritional problem? Am J Nephrol 7:253-256

4. Rizzoni G. Broyer M, Guest G. Fine R 1986 Growth retardation with chronic renal disease: scope of the problem. Am J Kidney Dis 7:261-265

5. Chan JCM. Kodroff MB, Landwehr DM 1981 Effects of 1,25-dihydroxyvitamin- $D_{3}$ on renal function, mineral balance, and growth in children with severe chronic renal failure. Pediatrics 68:559-57!

6. Kawaguchi Y, Kimura Y, Yamamoto M, Imamura N. Tukui I, Horiuchi N, Suda T, Ogura Y, Oda Y. Miyahara T 1983 Graded nephron mass reduction and renal synthesis of 1,25 -dihydroxyvitamin- $D_{3}$ in the rat. Metab Bone Dis Relat Res 4:333-336

7. Massry SG, Goldstein DA, Malluche HH 1980 Current status of the use of $1.25-(\mathrm{OH})_{2}-\mathrm{D}_{3}$ in the management of renal osteodystrophy. [editorial review] Kidney Int 18:409-418

8. Chesney RW, Rosen JF, Hamstra AJ, DeLuca HF 1980 Serum 1,25-dihydroxyvitamin- $\mathrm{D}_{3}$ levels in normal children and in vitamin $\mathrm{D}$ disorders. Am $\mathrm{J}$ Dis Child 134:135-139

9. Chesney RW, Hamstra AJ, Mazess RB, Rose P, DeLuca HF 1982 Circulating vitamin $\mathrm{D}$ metabolite concentrations in childhood renal diseases. Kidney Int 21: $65-69$

10. Salusky IB, Fine RN, Kangarloo H, Gold R, Paumier L, Goodman WG, Brill JE. Gilli G, Slatopolsky E, Coburn JW 1987 High dose calcitriol for control of renal osteodystrophy in children on CAPD. Kidney Int 32:89-95

11. Wilson L, Felsenfeld A, Drezner MK, Llach F 1985 Altered divalent ion metabolism in early renal failure: role of $1,25(\mathrm{OH})_{2}-\mathrm{D}_{3}$. Kidney Int 27:565573

12. Holliday MA 1987 Nutrition therapy in renal disease: adaptation to loss of tolerance. In: Murakami K. Kitagawa T, Yabuta K, Sakai T (eds) Recent Advances in Pediatric Nephrology. Excerpta Medica, Amsterdam, pp 51-60

13. Hellerstein S, Holliday MA, Grupe WE, Fine RN, Fennell RS, Chesney RW, Chan JCM 1987 Nutritional management of children with chronic renal failure. Pediatr Nephrol 1:195-211

14. Nakano M, Kainer G, Foreman JW, Ko D, Chan JCM 1989 The effect of exogenous rat growth hormone therapy on growth of uremic rats fed an $8 \%$ protein diet. Pediatr Res 26:204-207

15. Mehls O, Ritz E, Hunziker EB, Eggli P, Heinrich U, Zapf J 1988 Improvemen of growth and food utilization by human recombinant growth hormone in uremia. Kidney Int 33:45-52

16. Powell DR, Rosenfeld RG, Hintz RL 1988 Effect of growth hormone therapy and malnutrition on the growth of rats with renal failure. Pediatr Nephrol 2:425-430

17. Koch VH, Lippe BM, Nelson PA, Boechat MI, Sherman BM, Fine RN 1989 Accelerated growth after recombinant human growth hormone treatment of children with chronic renal failure. J Pediatr 115:365-371

18. Coburn JW, Slatopolsky E 1986 Vitamin D, parathyroid hormone, and renal osteodystrophy. In: Brenner BM, Rector Jr FC (eds) The Kidney, 3rd Ed. WB Saunders, Philadelphia, pp 1657-1729

19. Baginski ES, Foa PP, Zak B 1967 Microdetermination of inorganic phosphate phospholipids, and total phosphate in biological materials. Clin Chem 13:326-332

20. Analytical Methods for Atomic Absorption Spectrophotometry 1982 PerkinElmer Corp. Norwalk, CT, pp BC1-BC9

21. Johnson MA, Greger JL 1985 Tin, copper, iron, and calcium metabolism of rats fed various dietary levels of inorganic tin and zinc. J Nutr 115:615-624

22. Friedman AL, Pityer R 1986 Beneficial effect of moderate protein restriction on growth, renal function, and survival in young rats with chronic renal failure. J Nutr 1 16:2466-2477

23. Hostetter TH, Meyer TW, Rennke HG, Brenner BM 1986 Chronic effects of dietary protein in the rat with intact and reduced renal mass. Kidney Int 30:509-517

24. Laouari D, Kleinknecht C, Gubler M-C, Ravet V, Broyer M 1982 Importance of proteins in the deterioration of the remnant kidneys, independently of other nutrients. Int J Pediatr Nephrol 3:263-269

25. Ibels LS, Alfrey AC, Hant L, Huffner WE 1978 Preservation of function in experimental renal disease by dietary restriction of phosphate. N Engl J Med 298:122-126

26. Portale AA, Booth BE, Halloran BP, Morris Jr RC 1984 Effect of dietary phosphorus on circulating concentrations of 1,25-dihydroxyvitamin $\mathrm{D}$ and immunoreactive parathyroid hormone in children with moderate renal insufficiency. J Clin Invest 73:1580-1589.

27. Gershberg H 1960 Metabolic and renotropic effects of human growth hormone in disease. J Clin Endocrinol Metab 20:1107-1119

28. Westby GR, Goldfarb S, Goldberg M, Agus ZS 1977 Acute effects of bovine growth hormone on renal calcium and phosphorus excretion. Metabolism 26:525-530

29. Yeh JK, Aloia JF 1979 The influence of growth hormone on vitamin D metabolism. Biochem Med 21:311-322

30. Gray RW, Gartheaite TL 1985 Activation of renal 1,25-dihydroxyvitamin- $D_{3}$ synthesis by phosphate deprivation: evidence for a role for growth hormone. Endocrinology 1 16:189-193.

31. Massry SG, Coburn JW 1973 The hormonal and non-hormonal control of renal excretion of calcium and magnesium. Nephron 10:66-112

32. Contiguglia SR, Alfrey AC, Miller N, Butkus D 1972 Total body magnesium excess in chronic renal failure. Lancet 1:1300-1302

33. Sandahl CS, Gamelgaard J, Orskov H, Andersen AR. Telmer S, Parving HH $198 \mathrm{I} \mathrm{Kidney} \mathrm{function} \mathrm{and} \mathrm{size} \mathrm{in} \mathrm{normal} \mathrm{subjects} \mathrm{before} \mathrm{and} \mathrm{during} \mathrm{growth}$ hormone administration for one week. Eur J Clin Invest 11:487-490

34. Hirschberg R. Rabb H, Bergamo R, Kopple JD 1989 The delayed effect of growth hormone on renal function in humans. Kidney int 35:865-870

35. Tonshoff B, Mehls O, Heinrich U, Blum WF, Ranke MB, Schauer A 1990 Growth-stimulating effects of recombinant human growth hormone in children with end-stage renal disease. J Pediatr 116:561-566

36. Genentech Collaborative Study Group 1989 Idiopathic short stature: results of a one-year controlled study of human growth hormone treatment. J Pediatr 115:713-719

37. Wit JM, Fokker MH, deMuinck Keizer-Schrama SMPF, Oostdijk W, Gons M, Otten BJ, Delemarre-Van de Waal HA, Reeser M, Waelkens JJJ 1989 Effects of two years of methionyl growth hormone therapy in two dosage regimens in prepubertal children with short stature, subnormal growth rate, and normal growth hormone response to secretagogues. J Pediatr 115:720725

38. Wilson DP, Jelley D, Stratton R, Coldwell JG 1989 Nephropathic cystinosis: improved linear growth after treatment with recombinant human growth hormone. J Pediatr 115:758-760

39. Rudman D, Feller AG, Nagraj HS, Gergans GA, Lalitha PY, Goldberg AF, Schlenker RA, Cohn L, Rudman IW, Mattson DE 1990 Effects of human growth hormone in men over 60 years old. N Engl J Med 323:1-6 